\title{
Argentina: Enforcement and Effectiveness of Consumer Law
}

\author{
Pedro Aberastury \\ Universidad de Buenos Aires, Buenos Aires, \\ Argentina e-mail: pedro@aberastury.com
}

\author{
Estela B. Sacristán \\ Argentine Catholic University, Buenos Aires, \\ Argentina e-mail: es@bgcv.com.ar
}

https://doi.org/10.1007/978-3-319-78431-1_2

\section{Introduction}

Consumer protection, in Argentina, seems to be a work in progress. As a young field of study, it dates back to the year 1993, when the first law for the protection and defence of consumers was passed. After that first legislative decision, consumers found their way to be included in the text of the Constitution of the Argentine Nation on occasion of the 1994 constitutional reform. Subsequent amendments to the 1993 law, as well as civil laws dealing with consumers' rights, were passed in recent years. All these changes can be seen as a continuous legislative work aiming at a harmo- nization between the interests at stake, sometimes inspired by local case law and other times impulsed by the tangible need, among the inhabitants, of an effective, enforceable system of protection as consumers.

The resulting system is somewhat complex but sincere, aiming at a conciliation of interests and eventual full access to judicial redress no matter how small the claim may be. But, at the same time, and from a methodological-and prior-point of view, the system is protective, as we shall see, and, therefore, there seem to be no incentives for consumers to be proactive; rather, they rely on the defence provided by the legal framework or the case law.

In order to take a glimpse into the consumer protection system in Argentina, it seems appropriate to provide, in the very first place, some 
objective data that can help the reader get a full understanding of the physical and political reality that underlies said system.

\subsection{Physical and Political Environment}

Argentina is a country that has a total population-according to the census that was performed in 2010 of 40,117,096 inhabitants inside the national territory. Those inhabitants are located mostly in the Pampean and Metropolitan areas, where $66.3 \%$ of the national total is to be found. ${ }^{1}$ Besides, Argentina's mainland surface area comprises 2,780,400 $\mathrm{km}^{2} \quad(1,073,518$ square miles), thus rendering a population density of 14.4 inhabitants per $\mathrm{km}^{2}$.

Argentina offers a national consumer policy that that relies on several axioms. The consumer is considered as an entity entitled to protection, or as someone deserving defence against the other party. This protection or defence goal can be seen in the Constitution of the Argentine Nation, especially in Section 42, after the 1994 constitutional amendment: "consumers [.. .] have the right to the protection of [... .".2

According to said Section 42, the main constitutional goals are: (1) recognizing consumers and users of goods and services; (2) protecting their:

(a) right to the protection of their health, safety, and economic interests; (b) right to adequate and truthful information; (c) their freedom of choice and equitable and reliable treatment;

(3) assuring: (a) their education for consumption, (b) the defense of competition against any kind of market distortions, (c) the control of natural and legal monop- olies, (d) the control of quality and efficiency of public utilities, and (e) the creation of consumer and user associations.

\footnotetext{
${ }^{1}$ INDEC - Instituto Nacional de Estadísticas y Censos (2014), Preguntas frecuentes, http://www. indec.gov.ar/preguntas.asp (last accessed 14/1/2017).

${ }^{2}$ Section 42: "As regards consumption, consumers and users of goods and services have the right to the protection of their health, safety, and economic interests; to adequate and truthful information; to freedom of choice and equitable and reliable treatment. The authorities shall
} 
provide for the protection of said rights, the education for consumption, the defence of competition against any kind of market distortions, the control of natural and legal monopolies, the control of quality and efficiency of public utilities, and the creation of consumer and user associations. Legislation shall establish efficient procedures for conflict prevention and settlement, as well as regulations for national public utilities. Such legislation shall take into account the necessary participation of consumer and user associations and of the interested provinces in the control entities." According to the translation of the Constitution of the Argentine Nation, http://www.parliament.am/library/ sahmanadrutyunner/argentina.pdf (last accessed 14/1/2017).

Local governments, i.e., the provinces and the Autonomous City of Buenos Aires, within their powers, also perform duties related to Section 42 of the Consti- tution of the Argentine Nation, especially enforcement duties.

Consumers in Argentina enjoy access to education about their rights. For instance, at the national level of government, there are training courses, delivered by the Consumer Education and Training Area of the Dirección Nacional de Defensa del Consumidor, Subsecretaría de Comercio Interior, Secretaría de Comercio, Ministerio de Producción, Presidencia de la Nación. Teachers and schools often can contact that Area's webpage to download courses or teaching materials. ${ }^{3}$

ONG's, especially consumers' associations, play an important role in providing courses and teaching materials, and useful information for users and consumers. ${ }^{4}$

The awareness about consumer rights has been increasing among citizens and residents. ${ }^{5}$ At the local level, this awareness is enhanced by means of campaigns that are held both by the Government and the ONG's, and by means of education goals. For example, in the Autonomous City of Buenos Aires, the Consumer Education Program (Programa Educación en el Consumo), ${ }^{6}$ held since 2001, is aimed at teachers, school managers, parents and students of public and private schools of all levels, striving to promote reflection on consumers' rights and duties.

Underlying all these political and educational efforts, there is a pivotal constitu- tional provision: Section 42 of the Constitution of the Argentine Nation, already transcribed, ${ }^{7}$ as well as various laws, including Law 24.240 (Consumers' Defence Law) and its amendments, and the new Civil and Commercial Code (which is, from the formal point of view, a law). These are 
the main sources we can now lay our eyes on.

\subsection{Relevant Sources for Consumer Protection}

Apart from Section 42 of the Constitution of the Argentine Nation, Section 43 of said Constitution must also be stressed because it establishes a summary judicial remedy for consumers and consumers' associations, allowing for collective actions or lawsuits. ${ }^{8}$

\footnotetext{
${ }^{3}$ See: Dirección Nacional de Defensa del Consumidor (2014), Educación, https://www.argentina. gob.ar/produccion/consumidor/derechos (last accessed 14/1/2017).

${ }^{4}$ Ibidem.

${ }^{5}$ Shaver and An (2014), p. 43.

${ }^{6}$ See Buenos Aires Ciudad, Programa Educación en el Consumo,

http://www.buenosaires.gob.ar/ defensaconsumidor/programa-de-educacion-para-elconsumo (last accessed 14/1/2017).

${ }^{7}$ See footnote 2 .

${ }^{8}$ See footnote 2 to Section 42 . Section 43 says: "Any person shall file a prompt and summary proceeding regarding constitutional guarantees, provided there is no other legal remedy, against any act or omission of the public authorities or individuals which currently or imminently may damage, limit, modify or threaten rights and guarantees recognized by this Constitution, treaties or laws, with open arbitrariness or illegality. In such case, the judge may declare that the act or omission is based on an unconstitutional rule. This summary proceeding against any form of discrimination and about rights protecting the environment, competition, users and consumers, as well as about rights of general public interest, shall be filed by the damaged party, the ombudsman and the associations which foster such ends registered according to a law determining their requirements and organiza- tion forms" (emphasis is added), according to the translation of the Constitution of the Argentine Nation, http://www.parliament.am/library/sahmanadrutyunner/argentina.pdf (last accessed 14/1/2017)
}

Now, at the infra-constitutional or formally legislative level, there are various laws that protect the consumer: Law 19.511 (Argentine Metrical System Law), passed in 1972 and subsequently amended; Law 20.680 (Supply Law, a law that vests in the Executive Branch the power to fix maximum and minimum prices), passed in 1974 and subsequently amended especially by Law 26.991 (New Regu- lation of Production and Consumption Relations), 
passed in 2014; Law 22.802 (Fair Trading Law), passed in 1983 and subsequently amended; Law 24.240 (Consumers' Defense Law), passed in 1993 and subsequently amended, especially in 2014 by Law 26361; Law

25.065 (Credit Cards Law), passed in 1999 and subsequently amended; Law 26.992 (Observatory for Pricing and Availability of Consumables, Goods and Services), passed in 2014; Law 26.993 (Consumer Conflict Resolution Law), passed in 2014, that creates a service of previous conciliation in the consumer relations (COPREC). ${ }^{9}$

The Civil and Commercial Code, Law 26.994, enacted in 2014,10 also includes Consumer Law regulations in many of its articles or sections. They will be reviewed infra, at Sect. 6.3.

Local governments, within their powers, perform duties related to Section 42 of the Constitution of the Argentine Nation, especially enforcement duties, and have passed laws to achieve this aim.

\subsection{Present and Future, in the Light of a Young Tradition}

Today, the government seems to be continuing with the objectives set by previous governments in the field of consumer protection. The Dirección Nacional de Defensa del Consumidor, Subsecretaría de Comercio Interior, Secretaría de Comercio, Ministerio de Producción, Presidencia de la Nación (the national agency in charge of the consumers' protection), proclaims the policy of consumer defence as part of an inclusive country project, in which all the inhabitants are entitled to "access con- sumption". Under this policy, and from the consumers' defence viewpoint, a culture of rights is fostered, which culture is believed to be strengthened by a community that is informed, that knows about its rights and that exercises those rights. In this way, community participation and consumers' education are facilitated. ${ }^{11}$

\footnotetext{
Nation, http://www.parliament.am/library/sahmanadrutyunner/argentina.pdf (last accessed 14/162017).

${ }^{9}$ All these laws may be found at http://www.infoleg.gob.ar.

${ }^{10}$ See http://www.infoleg.gob.ar/infolegInternet/verNorma.do?id11/4235975.

${ }^{11}$ Ibidem, footnote 3 , above.
} 
We may currently feel familiar with all of these goals. But they can be said to be the result of a real revolution that took place in the twentieth century: a revolution that changed the way contracts are perceived.

In the 1930s and 1940s, in Argentina, there was a change in the concept of contract. The best example on this is Risolía's doctoral thesis, on sovereignty and crisis of the contract under the Argentine Civil law. ${ }^{12}$ In his thesis, Risolía analysed the irruption of new forms of contracting, especially the ones in which one of the contracting parties' free will was not precisely free.

In the 1960s, the Civil Code then in force-basically, the one drafted by Vélez Sársfield by the end of the nineteenth century-was massively amended. This amendment included provisions to protect the weakest contracting party; to obtain a remedy if rebus sic stantibus clause was altered; to obtain protection against abuse of rights.

The resulting new contract foundations reached a maturity that allowed for the application of the 1968 Civil Code amendments, as well as for critical government intervention in private contracts (e.g., by means of the Supply Law 20.680, passed in 1974, allowing for the official fixing of maximum prices).

Finally, in the 1993, Law 24.240 (Consumers' Defense Law) was passed. And then, in 1994, the Constitution of the Argentine Nation was amended to guarantee the protection of the consumers' rights, both from the substantive (Section 42) and the procedural (Section 43) points of view. The enactment of the new Civil and Commercial Code did not betray this trend; quite the contrary, as we shall see below (Sect. 6.3).

Argentina has always been open to Comparative Law and both the development of the concept of contract and the consumer protection system can be traced in European juridical orders.

\footnotetext{
${ }^{12}$ Risolía (1946).
} 


\subsection{French or Spanish Influence?}

The influence that is evident, both in Law 24.240 (Consumers' Defense Law) and in Section 42 of the Constitution of the Argentine Nation is French in the sense that the consumer protection has been codified. But that is the only point of comparison for neither Sections 42-nor 43-of the Constitution of the Argentine Nation nor Law

\subsection{0 are comparable to the French Code de la Consommation.}

The most evident influence in the wording of Section 42 of the Constitution of the Argentine Nation is the 1978 Constitution of the Kingdom of Spain. A comparative table can be drawn as follows:

\begin{tabular}{l|l}
\hline Spanish Constitution, Section 51a & $\begin{array}{l}\text { Constitution of the Argentine Nation, } \\
\text { Section } 42\end{array}$ \\
\hline "1. The public authorities shall guarantee the & "As regards consumption, consumers and \\
protection of consumers and users and shall, & $\begin{array}{l}\text { users of goods and services have the right } \\
\text { to the protection of their health, safety, and } \\
\text { by means of effective measures, safeguard } \\
\text { their safety, health and legitimate financial } \\
\text { interests. }\end{array}$ \\
\hline
\end{tabular}

(continued)

\begin{tabular}{l|l}
\hline Spanish Constitution, Section 51a & $\begin{array}{l}\text { Constitution of the Argentine Nation, } \\
\text { Section } 42\end{array}$ \\
\hline $\begin{array}{l}\text { 2. The public authorities shall make means } \\
\text { available to inform and educate consumers } \\
\text { and users, shall foster their organisations, } \\
\text { and shall provide hearings for such }\end{array}$ & $\begin{array}{l}\text { to adequate and truthful information; to } \\
\text { free- dom of choice and equitable and } \\
\text { reliable treatment. The authorities shall } \\
\text { organisations on all matters affecting their } \\
\text { members, under the terms to be established } \\
\text { by law. }\end{array}$ \\
$\begin{array}{l}\text { education for consumption, the defense of } \\
\text { competition against any kind of market } \\
\text { distortions, the control of natural and legal } \\
\text { monopolies, the control of quality and } \\
\text { efficiency of public utilities, and the creation } \\
\text { of consumer and user associations. } \\
\text { Legislation shall establish efficient } \\
\text { procedures for conflict prevention and } \\
\text { settlement, as well as regulations for }\end{array}$ \\
\hline
\end{tabular}




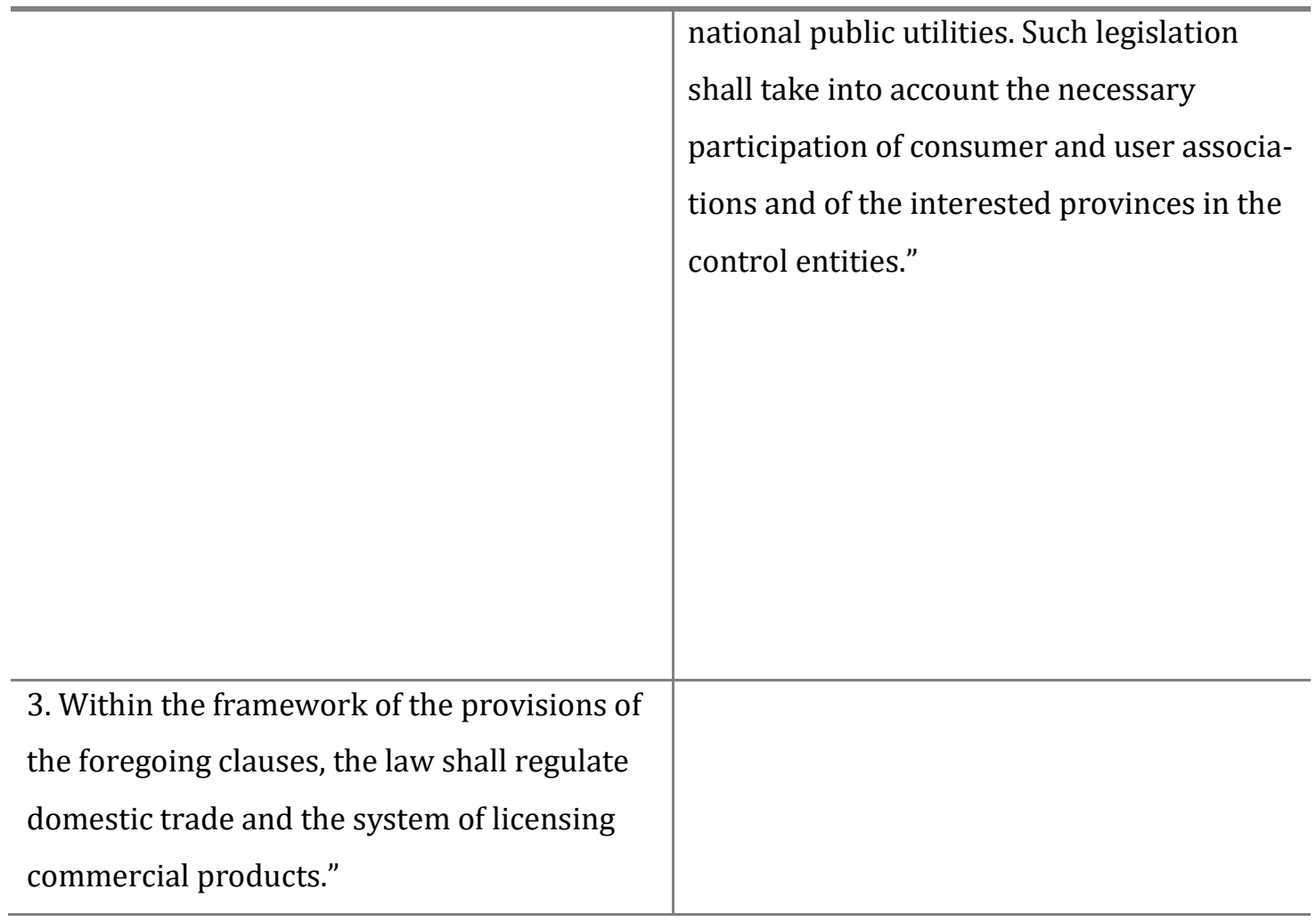

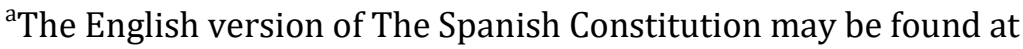
http://www.boe.es/legislacion/ constitucion.php (last accessed 14/1/2017)

Nevertheless, all this Comparative Law influence has developed, in Argentina, in a certain direction: the focus, ever since the Constitution of the Argentine Nation was amended in 1994, has been on taking for granted that the consumer is always the weakest party in the consumer relation, deserving protection. This has been enhanced by a recent greater concern towards consumers' access to information in a growing scenario of transparency and fair play. For example, an official system to compare prices of goods sold at supermarkets is currently being designed..$^{13}$ Also, private publications are available. ${ }^{14}$ We believe greater access to information will diminish the amount of cases brought before the administrative branch - and, subsequently or in an originary manner, the judicial branch-to be solved.

\footnotetext{
${ }^{13}$ Jueguen, Francisco (2016), Cómo funcionará el monitoreo informático de precios oficial, La Nación, 5 May 2016, http://www.lanacion.com.ar/1895547-como-funcionara-el-monitoreoinformatico-de-precios-oficial (last accessed 14/1/2017).

${ }^{14}$ For example, in the case of pharmaceutical products, we can consult Precios de Remedios, http:// www.preciosderemedios.com.ar (last accessed 14/1/2017).
} 


\section{Administrative Enforcement Mechanism}

Under Law 24.240 (Consumers' Defense Law), Section 41, the main authority in charge of consumer law is an administrative agency: the Secretaría de Comercio.

\subsection{Overview}

The Secretaría de Comercio is an agency within the Ministerio de Producción, which belongs to the Executive branch of government. The Secretaría de Comercio has two Subsecretarías: one devoted the Foreign Commerce, and one devoted to Internal Commerce. The latter is the Subsecretaría de Comercio Interior.

There is a Dirección Nacional de Defensa del Consumidor within the latter. That Dirección exercises its duties by administrative delegation. Therefore, from the bureaucratic point of view, the Dirección Nacional is not very outstanding. Never- theless, its powers are relevant pursuant to the effective application or enforcement of Law 24.240.

The authority of the Secretaría de Comercio is established in Law 24.240 (Consumers' Defence Law), especially Sections 41-44. The Secretario de Comercio is appointed by the Executive Power, a power of appointment that is vested on the President of the Nation under the Constitution of the Argentine Nation, Section 99.7.

\subsection{Federalism}

At the same time, and bearing in mind the federal organization adopted in Argentina, under Law 24.240 (Consumers' Defence Law), the Consumers' Defence Law shall be applied both at the national and at the provincial levels, 
and in the Autonomous City of Buenos Aires.

Both provinces and the Autonomous City of Buenos Aires are local enforcement authorities of Law 24.240 (Consumers' Defence Law).

\subsection{Powers}

Under Law 24.40, Section 43, the Secretaría de Comercio Interior has an important role to play in the Consumer Law universe. Among others, it has the following powers: Proposing regulations to the Law 24.240 and designing policies aimed at the consumers and users' protection for a sustainable consumption protecting the environment; taking part in their implementation by means of appropriate rulemaking15; keeping a national registry of consumers and users' associations; receiving and processing the concerns and complaints submitted by consumers or users; decreeing inspections and expert inquiries related to the enforcement of the law; requiring reports and opinions from public and private entities in relation to the matter of this law; decreeing, ex officio, or at the prior request of the party, that hearings be held, with the participation of the injured complainants, the presumed offender, witnesses and experts. Some of these powers may be subject to delegation from the national orbit to the local level.

\subsection{A Consumers' Viewpoint}

The exact name of the main authority and the manner in which it may enforce their consumer rights may not be so widely known and this can be verified by consulting the different social networks that hold pages devoted to receiving consumers' complaints: many consumers complain through social networks without knowing the name of the administrative authority that is in charge of handling their complaints.

However, at the national level, a website has been created by the Secretaría de Comercio so that consumers and users can electronically file-in, for free and with no professional counsel, their complaint, and agree on a date for a hearing. The system is subject to an economic limitation, ${ }^{16}$ and is aimed at the 
valuable goal of reaching amiable transactions, thus diminishing the administrative (and, eventually, judicial) caseload.

Consumers seem to be effectively conscious of the existence of consumer associations that protect them. At the same time, consumer associations are subject to strict requirements set forth in Law 24.240 (Consumers' Defence Law). ${ }^{17}$ This is due to the fact that, under Law 24.240 (Consumers' Defence Law), consumer associations, registered under Law 24.240, Section 43.b), receive governmental funds to perform their duties. ${ }^{18}$

There is a notorious use of social networks to pose informal complaints, bypassing the administrative agency and the consumer associations. At the same

\footnotetext{
${ }^{15}$ These regulations represent the exercise of a pouvoir réglementaire.

${ }^{16}$ See Sect. 4.2 below.

${ }^{17}$ Under Law 24.240, Section 56, the organizations aimed at the defence, information and education

of the consumer, must request official authorization to operate as such. They will be considered legal as far as they fulfil the following various duties set forth in the laws and bylaws. Under Law 24.240, Section 57, in order to obtain recognition as a consumers' association, each civil association must meet special conditions. See Sect. 5.2 below.

${ }^{18}$ See, for example, Resolución 73/2014, issued by the Secretaría de Comercio, http://www.infoleg. gob.ar/infolegInternet/anexos/230000-234999/230713/norma.htm (last accessed 14/1/2017).
}

time, companies are using social networks to improve communication and prevent consumer claims. ${ }^{19}$

There seems to be a lot to be done in the field of information disclosure: the only figures that could be located, covering administrative claims at the national level, correspond to the year 2005, and a very recent attempt at the publication of figures resulting from national statistics covering informal requests and complaints before the Administration, by means of a hotline, will be mentioned further on. ${ }^{20}$ As a result of the publication of an OECD report, we can see that, in 2005, in Argentina, under Law 24.240 (Consumers' Defence Law), there were 355 cases sanctioned by the administrative authority. ${ }^{21}$ And, as a result of the first attempts at publicizing informal complaints, we can 


\subsection{Specific Sectors That Have Their Own}

\section{Enforcement Mechanisms}

In Argentina there is a set of industrial activities that have been subject to publicatio by Congress. Going through a publicatio decision means that the specific activity at stake is subject to the service public regime. The service public regime consists, basically, in having the specific activity subject to two requirements: the provider will be under a duty to serve, and will not be allowed to charge any free market price; instead, an officially fixed price or rate (tarifa), set after a ratemaking administrative procedure, will be the only income the provider will receive from the user. This is the case of electricity transmission and distribution, ${ }^{23}$ natural gas transportation and distribution, ${ }^{24}$ water and sewerage services, ${ }^{25}$ among others.

Each service public has its own special laws and regulations (regulatory frame- work). For example, Law 24.065 regulates electric transmission and distribution duties and rights. Each regulatory framework includes regulations in order to handle complaints by users of the network. They include, as a duty, the exhaustion of

\footnotetext{
${ }^{19}$ This is the case, for instance, of electricity supply interruptions due to scheduled maintainance works.

${ }^{20}$ See footnote 48 , below.

${ }^{21}$ See OECD-Organization for Economic Co-operation and Development and Inter-American Development Bank (2006), Competition Law and Policy in Argentina, https://www.oecd.org/daf/ competition/Argentina-CompetitionLawPolicy.pdf (last accessed 14/1/2017), p. 19.

${ }^{22}$ See footnote 48 , below.

${ }^{23}$ Law 24.065, Section 1, http://www.infoleg.gob.ar/infolegInternet/anexos/04999/464/texact.htm (last accessed 14/1/2017).

${ }^{24}$ Law 24.076, Section 1, http://www.infoleg.gob.ar/infolegInternet/anexos/04999/475/texact.htm (last accessed 14/1/2017).

${ }^{25}$ Law 26.221, Section 2, http://www.infoleg.gob.ar/infolegInternet/anexos/125000-129999/ 125875/norma.htm (last accessed 14/1/2017).
} 
remedies system ${ }^{26}$ by which the user has to complain to the company, and then to the regulatory agency, and then the judicial instance would be available. This is all asserted as a matter of principle, because there are some cases in which the user-or an association representing him-may file a lawsuit directly before the Judiciary branch, as we saw supra, Sect. 1.2.

Apart from this, there are activities that were subject to publicatio at the time of the privatization of the relevant network and then they reached the stage of dereg- ulation, becoming a free activity in an open competition environment. ${ }^{27}$ The regu- latory framework used to include and currently includes regulations in order to handle complaints by users of the network, and they are similar to the ones described above. Again, this is all asserted as a matter of principle, because there are some cases in which the user-or an association representing him-may file a lawsuit directly before the Judiciary branch.

\section{Enforcement of Consumer Law Before the Judicial Courts}

In order to review the manner in which consumers can have access to the judicial system, it is appropriate to briefly review the way the judiciary is organized in Argentina.

As it was suggested in Section 1.1, Argentina is organized as a federal republic, composed of various provinces. There are two judicial orders: the federal judicial order, and the local or provincial judicial order (including, as a local judiciary, that of the Autonomous City of Buenos Aires). The federal judiciary consists in first instance federal judgeships, appellate federal courts of appeals, and a federal Supreme Court (Corte Suprema de Justicia de la Nación).

The local or provincial judicial organization varies from province to province. Each province has a Supreme Court of Justice, which is the highest judicial organ in the local or provincial sphere. Under Law 48, Section 14, judicial cases litigated in a province start and end within the judiciary system of that province. Only by exception may the case, that started in a province, be brought to the highest court of the country, i.e., the Corte Suprema de Justicia 
de la Nación, after the local Supreme Court of Justice has issued its ruling.

The main characteristics of the Argentine judicial system are: constitutional judicial review can be exercised by any judge or court of law independently from

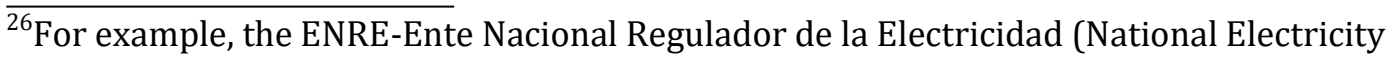
Regu- latory Entity), created by Law 24.065, publishes an accesible manual for electricity distribution users so that they get to know their rights and how to file-in their complaints, http://www.enre.gov.

ar/web/web.nsf/Files/manual\%20usuarios\%20ENRE.pdf/\$FILE/manual\%20usuarios\%20E NRE. pdf (last accessed 14/1/2017).

${ }^{27}$ See Decree 764/2000, http://servicios.infoleg.gob.ar/infolegInternet/anexos/60000$64999 / 64222 /$ texact.htm (last accessed 14/1/2017).
}

the sphere it belongs to (federal or local); the case or controversy requirement is to be fulfilled; standing to sue is also required; there is no case or controversy if there is unripeness or mootness; certain questions, such as political questions, are exempt from judicial review; there are typical individual lawsuits, and class actions; the Constitution of the Argentine Nation, Section 43, has established a summary judicial proceeding for constitutional rights violations to be brought by individuals or by consumer associations or other collective litigants such as the National Ombudsman (Defensor del Pueblo de la Nación); each province must guarantee the local admin- istration of justice.

\subsection{Consumer Disputes}

Consumer disputes can be posed before the Administration or before the judicial courts; or, directly before the judicial courts.

The administrative mediation system (Sistema Nacional de Arbitraje de Consumo or SNAC), ${ }^{28}$ created by Law 26.993 is a voluntary mediation system that is currently in force, and it aims at reconciling the opposing parties. Within the system, some disputes are excluded (e.g., claims against commercial airlines), some are included (e.g., medical insurance), and it is 
viable only if the firm has previously registered in the system. In case there is no agreement, the judicial justice is available (at the national level, the ordinary Commercial courts or the Federal Court of Appeals for Civil and Commercial Litigation-Cámara Nacional de Apelaciones en lo Civil y Comercial Federal, CNACyCF). In general, this system aims at satisfying con- sumers' pecuniary claims. In the provinces, this system is implemented by local mediation centers, and then the local judicial courts will be available. As it was stated in Sect. 2.5, certain services, that are declared service public, have their own mediation system to be held before the specialized regulatory agency. Therefore, if someone suffers damages in an electrical appliance due to over voltage, the damages claim for the destructed appliance will be filed in before the service provider and then before the regulator.

The choice of the reviewing court depends on the subject matter. Sanctions are typically reviewed by the Cámara Nacional de Apelaciones en lo Contencioso Administrativo Federal-CNACAF because they are the result of an administrative proceeding in which due process should be guaranteed and they represent the sanctioning decision of a national agency. Other matters, such as the judicial claim based on service interruption (based, in itself, on contested billing, for instance) or wrongful provision of a service (e.g., refusal of the medical insurance company to cover certain expenses), are reviewed by the Cámara Nacional de Apelaciones en lo Civil y Comercial Federal-CNACyCF. Finally, any damage suffered by a

\footnotetext{
${ }^{28}$ Sistema Nacional de Arbitraje de Consumo, https://www.argentina.gob.ar/sistemanacional-de- arbitraje-de-consumo (last accessed 14/1/2017).
}

consumer in a typical private consumer relation will belong in the ordinary national Commercial courts ${ }^{29}$ or their similar ones in the provinces.

Currently, there are no judicial courts exclusively devoted to consumer disputes. Under Section 53, Law 24.240 (Consumers' Defence Law), the rule will be the adoption of a summary judicial proceeding, unless the judge decides that an ordinary judicial will better serve the consumer's protection. A typically summary proceed- ing, legislated in Section 43 of the Constitution of the Argentine Nation and in the various administrative litigation laws (both 
federal and provincial), is the acción de amparo, which may be filed in together with an injunctive relief petition, either before a federal judgeship or a provincial judgeship. The acción de amparo, as a rule, is not subject to the exhaustion of administrative remedies, though it will be subject to the case or controversy requirements; it may be impulsed to challenge the decision of an administrative agency, or the decision of a private party. The Constitution of the Argentine Nation, Section 43, allows for judicial review on constitutional grounds within an acción de amparo, and this review may be exercised both by a federal or a provincial judgeship or court.

Section 53 of Law 24.240 (Consumers' Defence Law) guarantees free or gratuitous justice and, under said Section 53, this benefit will cease in case the defendant shows evidence of the consumer's solvency or ability to pay judicial expenses. At the same time, consumer associations, under Section 56 of Law 24.240 (Consumers' Defence Law), must provide legal aid to consumers who contact them independently from the financial situation of the consumer. Unfortunately there are no publications regarding consumer satisfaction in the field of consumer disputes before judicial courts.

The main advantages of the system of consumer access to justice may be assessed in the light of the principles that judicial courts usually apply in Consumer Law cases. A typical principle that is applied is that of in dubio pro consumer, which means that, in case of doubt, the most favourable decision for the consumer shall be adopted. ${ }^{30}$ This principle is currently included in Section 1095 of the new Civil and Commercial Code in force, and has been subject to objections in the field of service public. ${ }^{31}$

The CNACAF has adopted the in dubio pro consumer principle, interpreting that "the protection of the weakest party in the consumer relation is based on a 'pre- sumption of legitimate ignorance'", 32

\footnotetext{
${ }^{29}$ An example of the National Commercial Court of Appeals consumer defence case law can be seen

at http://www.pjn.gov.ar/Publicaciones/00020/00034853.Pdf (last accessed 14/1/2017).

${ }^{30}$ Argentine Supreme Court of Justice of the Nation, Banco de la Nación Argentina c/Monti, Aldo Horacio s/cobro de pesos, dated 11 November 2003, record B. 3885. XXXVIII, Fallos:326:4541 (2003); Caja de Seguros S.A. c/Caminos del Atlántico S.A.C.V., dated 21 March 2006, record

C. 745. XXXVII, Fallos:326:695 (2006). All of them may be found at www.csjn.gob.ar (last
} 
accessed 14/1/2017).

${ }^{31}$ Sacristán (2004), pp. 449-463.

${ }^{32}$ CNACAF, Sala II, Ombú Automotores S.A. c/Secretaría de Comercio e Inversiones-Disp.

DNCI N²20/97, record 23.921/1998, dated 4 March 1999.

\subsection{Main Shortcomings of the Judicial Enforcement of Consumer Rights in Argentina}

In a scene in which it is relatively easy to litigate before the judicial courts, perhaps the main shortcomings relate to the distribution horizon of all the costs involved in cases that shall be governed by the principle of in dubio pro consumer.

This distribution horizon has been facing, basically ever since 1994, the creation of a case law that does not seem to hesitate before consumer claims, and a body of administrative legislation or regulations-dictated under pouvoir réglementaire - that have followed suit.

Regarding liberalized or free market business activities, costs derived from judicial rulings that protect-or perhaps over protect-the consumer shall, hypo- thetically, be transferred to final prices paid by the rest of the consumers of that firm. As to activities that have been declared service public, subject to officially fixed rates-which have, in turn, suffered the freezing set forth by Section 8 of the Emergency Law 25561 passed in January 2002, currently in force until December 2017, the distribution of the costs derived from consumer claims becomes crucial.

\section{SpecialisedAgencies and theEnforcement of}

\section{Consumer Law}

In Argentina, the specialised agency in charge of enforcement of consumer law is the Dirección Nacional de Defensa del Consumidor, an agency stemming from Section 42 of the Constitution of the Argentine Nation and Law 24.240. It has wide powers ${ }^{33}$ that include, essentially, coordinating the consumer 
protection system.

The Dirección Nacional has three sectors: one devoted to consumer advocacy; another one in charge of the National System of Consumer Arbitration (SNAC); and a Dirección de Protección Jurídica del Consumidor, a bureaucratic agency in charge of the effective legal protection of the consumers. ${ }^{34}$ The Dirección Nacional has its head office at Avenida Julio A. Roca 651 (1322), Ciudad Autónoma de Buenos Aires, Argentina and it has branches all over the country, in the different provinces. In addition to this, there are centers of personalized assistance to the consumer and a toll-free line of Consumer Information. Regarding claims, they may be posed online, at http://www.consumoprotegido.gob.ar.

\footnotetext{
${ }^{33}$ According to Decree 1070/2014, http://servicios.infoleg.gob.ar/infolegInternet/anexos/230000- 234999/232058/norma.htm (last accessed 14/1/2017).

${ }^{34}$ See the Organigrama at https://www.argentina.gob.ar/sites/default/files/defensaconsumidor_ organigrama_0.pdf (last accessed 14/1/2017).
}

\subsection{Administrative Proceedings}

Consumer disputes, before the Dirección Nacional, take between 6 months and a year on average to be solved, depending on the proceeding. The Dirección Nacional has two different proceedings for dispute resolutions: the Prior Conciliation Service on Consump- tion Relations (COPREC), and the National System of Consumer Arbitration (SNAC).

The COPREC establishes three instances: a first obligatory pre-judicial instance in which there is a conciliation between the consumer and the claimed company or companies in which an enrolled conciliator takes part. In case the parties do not reach an agreement, there is a Consumption Relations Audit (to repair the direct damage for an amount up to 15 minimum wages (approximately US\$ 7.100). The Judicial Jurisdiction of Consumption (for the full reparation of damage up to 55 minimum wages (approximately US\$ 26.00035), has not been implemented.

The SNAC handles consumption cases at the request of a consumer. It is 
necessary to file in the corresponding arbitration form before the SNAC. The consumer will be called for a conciliation hearing, within 15 days, and the hearing will be presided by a mediator. If the company is not a member of the SNAC, once the arbitration request has been filed, the claimed company is notified so that, within 5 days, it can accept or reject the requested arbitration. If the claimed company does not accept the requested arbitration, the file will be sent to the competent authority to be solved. If arbitration is accepted or if the company is a member of the SNAC, an arbitration (administrative) tribunal shall be established. The claimed company shall be given 10 business days to present the case and provide evidence. After the expiration of the deadline, a hearing date is set.. In case an agreement is reached, an arbitration award will be issued, subject to subsequent approval. If one of the parties does not attend the hearing or an agreement is not reached, the tribunal will go on to make a resolution by passing an arbitration award which has binding effect and enforceability: it can be enforced before a judicial court in case of noncompliance.

\subsection{Outcomes of the Administrative Proceedings}

Unfortunately it is not easy to locate, online, statistics reflecting consumers' or merchants' satisfaction, apart from the statistics published by the Government of the Autonomous City of Buenos Aires, related to the amount of complaints that are administratively and judicially handled ${ }^{36}$ and some national level statistical infor- mation that has begun to be published very recently related to requests and com- plaints filed in before the national Administration. ${ }^{37}$ Nonetheless, the advantages of the enforcement of consumer rights before a specialised agency are evident: SNAC is an extra-judicial arbitral mechanism that, at the same time, is voluntary, agile and free of charge. The role of the COPREC can also be stressed, for it allows for the conciliation of disputes below approximately US\$26.000.

However, there are a number of shortcomings that can be observed in the system. For instance, consumers have expressed difficulties in having access to the website www.consumoprotegido.gov.ar and in uploading documents; an 
online help desk or a link to frequently asked questions is most needed; there seems to be a substantial lag between the complaint filing date and the date for the scheduled conciliatory hearing; the quantity of registered conciliators seems to be insufficient.

\footnotetext{
${ }^{35}$ See Infobae, El salario mínimo, vital y móvil sube a $\$ 8.060$, http://www.infobae.com/2016/05/19/
}

1812812-el-salario-minimo-vital-y-movil-sube-8060/ (last accessed 14/1/2017). The rate of exchange between ARS and US\$ maybe consulted at Dolar Hoy, http://www.dolarhoy.com (last accessed 14/1/2017).

\footnotetext{
${ }^{36}$ See: Dirección General de Estadística y Censo - Ministerio de Hacienda GCBA (2015), Anuario Estadístico - Ciudad de Buenos Aires, http://www.estadisticaciudad.gob.ar/eyc/wpcontent/ uploads/2016/10/anuario_estadistico_2015.pdf (last accessed 14/1/2017), especially pp. 343-345. ${ }^{37}$ Ministerio de Producción - Presidencia de la Nación, Telefonía móvil, bancos yelectrodomésticos encabezaron el ranking de reclamos de los consumidores en 2016, http://www.produccion.gob.ar/ telefonia-movil-bancos-y-electrodomesticosencabezaron-el-ranking-de-reclamos-de-los- consumidores-en-2016/ (last accessed $16 / 1 / 2017$ ) is an official publication that was released on 14 January 2017. Its text provides interesting figures at the national level and shows a decision to publicly disclose statistics: "The Dirección Nacional de Defensa del Consumidor produced the2016 statistics on requests and complaints posed by consumers and users. The sectors that gathered the most requests were mobile communications, banks and financial entities and electric home appliance purchases and technical repair services. Complaints through the consumer defence hotline: (.. .) 235.676 requests were received from January through December 2016. (...). Complaints before the COPREC: (.. .) 35.007 complaints were received (.. .). Complaints before the SNAC: (... .) Between January and December 2016, 1.113 requests for arbitration were filed in. (...)."

${ }^{38}$ See Registro Nacional de Asociaciones de Consumidores, https://www.argentina.gob.ar/ produccion/consumidor/asociaciones (last accessed 15/1/2017).
}

\section{ConsumerOrganisations and Enforcement of Consumer Law}

According to an official webpage, www.consumidor.gov.ar, the consumers' associ-ations registered in Argentina vary in number along the different jurisdictions. ${ }^{38}$ For example, 35 may be found in the province of Buenos Aires; 
1 may be found in the province of Córdoba. Considering that there are 23 provinces in Argentina, there is a high number of provinces that have no registered consumers' associations.

Nevertheless, an association, registered in a given province, may have branches in other provinces. ${ }^{39}$ This is due to the fact that, according to the bylaws, ${ }^{40}$ consumer organizations which are set up as non-profit civil associations with legal capacity under Law 24.240, Sections 55 and 56 among others, are authorized to operate in the national jurisdiction.

\subsection{Anatomy of the Consumers' Associations}

A consumers' and users' association is defined as any organization constituted by private individuals, independently from all economic, commercial or political interests, aimed at guaranteeing and providing protection and advocacy for consumers and at promoting information, education, representation and respect of their rights. Law 24.240, Section 57, requires that, in order to be recognized as a consumer organization, "the non-profit civil associations shall comply with general requirements, as well as the following special conditions: a) they shall not be able to participate in political party activities; b) they shall be independent from all type of professional, commercial and productive activities; c) they will not be allowed to receive donations or contributions from commercial or industrial companies or private, state, national or foreign suppliers of services; they will not be allowed to include advertisements in their publications".

On the other hand, and in the field of authorization to operate, Law 24.240, Section 56 establishes that "[t]he organizations that have as a main objective the defense, information and education of the consumer, will have to request authorization to the competent authority to operate as such." It will be understood that they comply with such objective when they devote themselves to: (a) ensuringenforcement of laws;

(b) proposing the enactment of legislation or legal or administrative measures aimed at 
${ }^{39}$ This is the case of Acción del Consumidor, Adelco, a consumers' association that has filiales in Santa Fé, Santo Tomé and Tucumán, according to Acción del Consumidor, Autoridades y filiales, http://www.adelco.org/index.php/autoridades-y-filiales/ (last accessed 14/1/2017). ${ }^{40}$ Resolution 90/2016, which repealed the old Resolution 461/1999. The former may be found at: http://servicios.infoleg.gob.ar/infolegInternet/anexos/260000264999/261225/norma.htm (last accessed 14/1/2017). Resolution 90/2016, Section 1, establishes that: “The consumers' associations that are incorporated as civil associations (.. .) shall fulfil the following requirements in order to act at the national level once they are registered or re-registered before the National Registry of Consumers' Associations: a) Possess physical premises (.. .); b) count on physical means of dealing with consumers' and users' requests, at the association's premises, at least three days a week and for fifteen hours per week. c) Own their own internet domain (.. .). d) Count on means of communi- cation with the consumers, such as fixed or mobile telephone lines, e-mail address, social network, etc. e) Own an active banking account at the Banco de la Nación Argentina (.. .)." And Section 5 sets forth the conditions under which the association may remain at registered before the registry: "a) The fulfilment of the duties set forth in Section 1. b) Annual updating of all the information required (...) to be submitted to the Enforcement Authority, in accordance with the regulations guiding the submittal of accounting statements (.. .). c) Adequate notice, to the Enforcement Authority, regarding meetings (.. .) under the same requirements established by the laws for civil associations. d) Submittal of the association's Annual Management Report (.. .)."

protecting or educating consumers; (c) cooperating with various bodies for the improvement of consumer legislation or the like; (d) receiving complaints from consumers and promoting friendly solutions; (e) defending and representing consumer interests before the courts or competent authorities; (f) advising consumers on con- sumption matters; (g) performing and disclosing market research studies, quality control studies, price statistics, and provide any other information of interest for consumers; (h) promoting consumer education; among otherobjectives.

Besides, Law 24.240, Section 58, states that “[c]onsumers' organizations shall be enabled to make complaints, deriving from breach of this Law, on behalf of consumers of goods and services before manufacturers, merchants, agents or corresponding suppliers of service." Finally, Law 24.240, Section 55, states that " $[\mathrm{t}]$ he consumer associations registered as legal entities have legal standing to sue when consumer interests are objectively affected or threatened (.. .)." Therefore, they have a legally established standing to sue. ${ }^{41}$ 


\subsection{The Role of Consumers' Associations}

Consumers' associations can be appraised as legal instruments that operate not as a defence but as a balance factor, as opposed to the alternative methods regulated by Law 24.240. In this way, those associations guarantee a system by which consumers may access and participate in the socioeconomic market.

Consumers' association stand as an undoubted means of assuring equality and social reliability. Under law 24.240, Section 57, consumers' associations cannot participate in partisan politics, must be independent from all type of professional, commercial and productive activities; and cannot accept donations or contributions arising from said activities.

It can be said that the recognized consumers' associations, as objective, impartial and modest entities, play an important mediation role. They deal with the complaints under an imperative of prevention, clarifying misunderstandings and ending unrest; they approach the substantive issue with due respect and understanding towards the parties and, bearing in mind the transparency principle, they achieve, in most of the cases, immediate satisfactory agreements.

By promoting friendly solutions between consumers and the liable ones, a consumers' association is cost-saving at the administrative stage. At the same time, judicial costs are avoided because the long lags the judicial organization assures, and its costs, are bypassed.

Finally, and from the point of view of professional counsel, a consumers' associ- ation-the same as any other inhabitant of Argentina-does not need legal counsel in

\footnotetext{
${ }^{41}$ Apart from consumers' associations, the Defensor del Pueblo de la Nación (an organ established by the Constitution of the Argentine Nation in the sphere of the Legislative Branch of government) has legal standing to sue under Law 24.240, Section 52.
} 
order to file in a claim before the Administration. ${ }^{42} \mathrm{And}$, at the judicial stage, free legal aid is always available, for example, through the Buenos Aires Lawyers Bar. ${ }^{43}$ Both guarantees facilitate the effective participation not only of consumers but also of consumers' associations before the Administration and before the Judiciary.

\section{An Ordre Public Law and Its Private Regulation and Enforcement}

In Argentina, in the area of economic rights, and from a general viewpoint, it can be said that the irruption of the recognition of consumption relations meant irrupting in the existing system: the Law 24240 principles shall always prevail, as stated by its Section 3, since said Law is an ordre public law. This feature implies that private conventions that oppose Law 24.240 shall automatically be passed over or ignored. At the same time, there seems to be an agreement, among authors, in the sense that the interpretation of the Law 24.240 shall always be guided towards the consumers' protection (in dubio pro consumer principle). This finding arises not only from the legislators' intent but also from the wording of Law 24.240, Section 3: "In case of doubt regarding the interpretation of the principles that this Act sets forth, the most favorable one for the consumer shall prevail." Therefore, Law 24.240 shall always be construed for the consumer and not against him.

This apparent airtight system does not hinder the application of other norms or principles that sometimes balance the imbalanced system.

\subsection{Ethical Standards}

Companies endeavor to apply ethical guidelines of consumption. In some fieldse.g., banking entities, ${ }^{44}$ associations of companies of direct sale ${ }^{45}$-there are Codes 


\footnotetext{
${ }^{42}$ Law 19.549 (Administrative Procedure Act), Section 1(i), http://servicios.infoleg.gob.ar/ infolegInternet/anexos/20000-24999/22363/texact.htm (last accessed 14/1/2017).

${ }^{43}$ See Colegio Público de Abogados de Capital Federal, Reglamento del Consultorio Jurídico Gratuito,

http://www.cpacf.org.ar/files/reglamentos/reglamento_consultorio_juridico_gratuito.pdf (last accessed 14/1/2017).

${ }^{44}$ Santander, Código General de Conducta, http://www.santander.com/csgs/StaticBS?blobcol1/4 urldata\&blobheadername $1 / 4$ content-type\&blobheadernamét/4 Content-Disposition\& $1 / 4$ blobheadername3 appID\&blobheadervalue1 application\%2Fpdf\&blobheadervalue2 inline $\%$ 3Bfilename\%3D837\%5C944\%5CCódigo+General+de+Conducta.pdf\& blobheadervalue $31 / 4$ santander.wc.CFWCSancomQP01\&blobkey $1 / 4$ id\&blobtable $1 / 4$ MungoBlobs\& blobwhere $1 / 41278708790053 \&$ ssbinary $1 / 4$ true (last accessed 14/162017), Section 20.

${ }^{45}$ Cámara Argentina de Venta Directa, Código de Éica, http://www.cavedi.org.ar/page.php? language $1 / 4$ sp\&section $1 / 4$ codigo-de-etica\&action $1 / 4$ prefacio (last accessed 14/1/2017).
}

of Conduct, and some of them regulate relations between the company and the consumer clients.

\subsection{Construing Law 24.240 in the Light of Other Laws}

Regarding consumption, Law 24.240 can be construed by means of an integration of legislation. In this way, Law 24.240 can be interpreted in the light of Law 22.802 (Fair Trading Law), or in the light of Law 25.156 (Antitrust Law), among others. The same happens when Law 24.240 is interpreted together with any other general or special law which is, in turn, applicable to consumption relations.

In the field of liability for goods or services, Law 24.240, Section 40, establishes strict and joint liability of the whole marketing chain. The only cause of liability exclusion would be the duty to prove that the cause of the damage has been external, beyond the control of the party. An exception to this principle is the case of the carrier who can bypass liability upon a showing that the damage or defect of the thing was not caused in the course of transport. 


\subsection{Law 24.240 and the New Civil and Commercial Code}

The Civil and Commercial Code, Section 7, regulates the temporary effectiveness of the laws in general: "The laws shall be applied to the consequences of the existing juridical relations and situations". Besides, the Civil and Commercial Code, Section 7, states that "The new supplementary laws shall be inapplicable to the contracts that are being executed, excepting the norms that are more favorable to the consumer in the consumption relations." Therefore, the new Civil and Commercial Code is certainly to be applied to many consumption relations.

Apart from these two important Civil Law regulations, the following rules may be found in the new Civil and Commercial Code:

1. Sections 11 and 14 regulate the dominant position on the market and collective rights, respectively.

2. Sections 984 to Section 989 regulate the so-called standard-term contracts.

3. Section 1073 to Section 1075 regulate contratos conexos (connected contracts), and said Sections may be applicable to consumption contracts.

4. Later on, the Civil and Commercial Code regulates consumer contracts: (1) one chapter, on consumption relations, norms the so-called consumption relation and the consumer (Section 1092), the consumer contract (Section 1093), the interpre- tation and preferential application of norms (Section 1094) and the interpretation of consumer contracts (Section 1095). (2) A second Chapter, on consent forma- tion, covers abusive practices (Section 1096 to Section 1099) and information and advertising aimed at consumers (Section 1100 to Section 1103). (3) A third 
Chapter prescribes about contracts entered into off-commercial premises (section 1104); distance contracting (Section 1105); use of electronic media (Section 1106); information regarding electronic media (Section 1107). (4) A fourth Chapter covers unfair contract terms (Section 1117); control of clauses included in a consumption contract (Section 1118); general interpretation rules (Section 1119); abusive legal situations (Section 1120); limitations (Section 1121); and the judicial control of abusive clauses (Section 1122).

5. The Civil and Commercial Code regulates banking contracts (Section 1384 to Section 1389), including banking contracts between banks and consumers and users.

6. Finally, Section 2100 and Section 2111 of the Civil and Commercial Code, regulate the consumption relations arising from time-shares and private cemeteries.

\section{Enforcement Through Collective Redress}

In the field of consumption, the so-called "collective incidence legal action" has been regulated since 1993 when Law 24.240 was enacted. Currently, collective incidence legal actions are regulated in Law 24.240, Section 54 in particular:

To reach a conciliatory agreement or transaction, previous notice must be served at the office of the Public Prosecutor -unless this office is, in itself, the plaintiff filing in the collective incidence legal action-, in order to decide regarding the adequate consideration of con- sumers' or aggrieved users' interests. The judicial approval will require a reasoned judicial decision. The agreement will have to be respectful of the possibility, for individual con- sumers or users, to opt-out from the effects of judicial solution adopted for the case.

The judicial decisions favorable to the claim will have the force of res judicata for the defendant and for all the consumers or users that are in similar conditions, except for those who expressly opt-out before the judicial decision is issued, under the terms and conditions the judge establishes.(.. .) (emphasis added)

The effects of the judicial decision are general, unless certain consumers or users decide to opt-out. The effective opting-out possibility is, at the times these lines are written, a pending matter of regulation. ${ }^{46}$ 


\footnotetext{
${ }^{46}$ See: Sacristán (2016), pp. 199-213, regarding a Supreme Court judicial decision that blocked a natural gas production, transportation and distribution price increase for the natural gas users throughout Argentina (excepting the ones entitled to social rates).
}

\section{Sanctions for Breach of Consumer Law}

Law 24.240 sets forth different kinds of sanctions. The most frequent ones, established in Section 47 of said law, consist in fines plus publication of a notice (regarding the sanction applied) in a main nationally distributed newspaper.

Besides, there can be punitive damages under Section 52 bis. The wording of Section 52 bis has caused many objections. ${ }^{47}$ The amount established in Law 24.240, Section 47.b. is that of ARS 5 million (approximately US\$350,000). The punitive damages regulated in Law 24.240, Section 52 bis and Section 47.b can be construed in the light of the criteria set forth in Law 24.240, Section 49 , i.e., damage, position in the market, valuation of the benefit obtained, seriousness of risks or social damages and their generalization, recidivism.

\section{$9 \quad$ ADR and Consumer Disputes}

In Argentina, ADR mechanisms, as applied to consumer relations, are mostly overseen by the SNAC (National System of Consumer Arbitration). ${ }^{48}$ Its jurisdiction encompasses consumption relations defined by Law 24.240, and its powers may be exercised throughout the whole national territory.

The SNAC is regulated by Decree $1070 / 2014,{ }^{49}$ which empowers it to manage the national registry of consumer associations, the registry of institutional arbitrators and the registry of public offers of endorsement to the SNAC; receive and assess the arbitration requests filed in by consumers; intervene in arbitration agreements; take part in arbitrator appointment, making the draw of arbitrators; take action in the matter of notifications, follow up and control of filings, deadlines, evidence produc- tion and record closing; keep the register of arbitration awards and adjudications; produce statistics.

In order to perform its duties, the SNAC acts under these principles ${ }^{50}$ : 
willfulness (parties opt for these proceedings as a method of disputes resolution); gratuity (arbitration proceedings are free for both parties, and no professional counsel is needed); simplicity and speed (arbitral proceedings last up to 120 business days, even if parties may agree on an extension); confidentiality (there is privacy and

\footnotetext{
${ }^{47}$ Stiglitz and Pizarro, even if expressing that the amendment "deserved praise", considered that the

legal norm meant "spoiling" the legal acceptance of the institution, that will become nothing but a source of juridical insecurity and possible inequality. See Stiglitz and Pizarro (2009), pp. 949-960. ${ }^{48}$ See Sect. 4.1 above.

${ }^{49}$ Decree 1070/2014, http://servicios.infoleg.gob.ar/infolegInternet/anexos/230000234999/ 232058/norma.htm (last accessed 14/1/2017).

${ }^{50}$ Ministerio de Producción - Presidencia de la Nación (2016), Sistema Nacional de Arbitraje de Consumo, http://www.produccion.gob.ar/sistema-nacional-de-arbitraje-del-consumo/ (last accessed 14/1/2017).
}

confidentiality on the arbitral procedure and the corresponding arbitration award; parties may agree on the publication of the award); impartiality and balance between the parties (there is one arbitrator for each party, plus a third arbitrator; strict qualification and solvency requirements are established; among other requirements); binding effect and enforceability (the award is binding and can be enforced before a judicial court in case of non-compliance by any of the parties).

It may be affirmed that the SNAC supplements the role judicial courts play, making the whole of the consumer protection more complete, and has been con- ceived to recompose the deteriorated relations between suppliers of goods and services and consumers or users. By means of the arbitration proceeding, the parties to a consumption relation can settle their differences, with similar effects to the ones obtained at the judicial courts, quickly and in an agile fashion. 

Enforcers and ConsumerOrganisations

Argentina is a member of the regional integration entity Mercado Común del Sur (MERCOSUR).

In 1994, one of its organs-the Common Market Group (GMC)-passed Reso- lution 126/1994, which established that, until a common regulation for consumer protection is enacted, each State Member shall apply its own consumer protection legislation to the goods and services which are marketed in its territory.

By means of Directives 1/1995, 17/1996 and 18/1996, various Technical Com- mittees were created within the MERCOSUR Trade Commission (CCM). The Technical Commission $\mathrm{N}^{\circ} 7$ (CT $\mathrm{N}^{\circ} 7$ ), devoted to consumer protection, was set up with the fundamental mission of drafting a Bill for a Consumer Regulation for the

MERCOSUR.

So far, the GMC, by recommendation of $\mathrm{CT} \mathrm{N}^{\circ} 7$, has issued several Resolutions on consumers protection:

- Resolution 123/1996, defining fundamental concepts regarding Consumer Pro- tection Law;

- Resolution 124/1996, establishing a Bill of Consumer Basic rights;

- Resolution 125/1996, setting forth concrete guidelines to achieve the effective health and safety protection of consumers;

- Resolution 126/1996, stating the criteria to which advertising of goods and services aimed at consumption will have to adjust;

- Resolution 127/1996, later replaced by Resolution 42/1998, establishing the conditions and scope that every contractual guarantee of goods has to comply with.

However, these Resolutions are not in force because their enforceability was conditioned to the enactment of "Common Regulation for Consumer Protection", which was never passed.

On 17 December 1996, the CMC subscribed, in Fortaleza (Brazil), the Protocolo de Santa María sobre Jurisdicción Internacional en Materia de 
Relaciones de Consumo (Santa Maria Protocol on International Jurisdiction on Consumption Relations). ${ }^{51}$ But during the XXV Meeting of the Trade Commission of MERCOSUR, held in Montevideo, on 9 and 10 December 1997, the Santa María Protocol was rejected. This led to both Resolution GMC 123/1996 and the Santa Maria Protocol to lose legal value.

In 2002, under the new Protocolo de Olivos (Olivos Protocol), ${ }^{52}$ MERCOSUR created a Permanent Review Arbitral Tribunal.

In the LXIII Ordinary Meeting of $\mathrm{CT} \mathrm{N}^{\circ} 7$, which took place in Rio de Janeiro on 18 and 19 August, 2010, there was an agreement on a "Bill on Applicable Law to International Consumer Contracts".

Also, in 2003, Argentina and Uruguay suggested using the Santa Maria Protocol as a model of a future Inter-American Convention. ${ }^{53}$ Consumer Law has been included in the agenda of the Séptima Conferencia de Derecho Internacional Privado (CIDIP VII). ${ }^{54}$

\section{Concluding Remarks}

The Argentine experience in the field of consumer protection, so far, seems to be positive as it has allowed consumers to have protection tools in small claims disputes. Besides, the orderly functioning of governmental entities and arbitral tribunals make it possible to receive and handle complaints from affected consumers. In general, the design renders a relatively simple, speedy and cost-saving resolution of possible Consumer Law disputes, as opposed to having to face a long judicial process.

The existence of governmental agencies empowered to deal with the possible conflicts and to protect the consumer has been a serious step to provide Constitution of the Argentine Nation, Section 42, with legal effectiveness. More recently, and with the aid of the internet, consumer claims have been facilitated.

\footnotetext{
${ }^{51}$ See MERCOSUR/CMC/DEC $N^{\circ}$ 10/96 - Protocolo de Santa María sobre Jurisdicción Internacional en Materia de Relaciones de Consumo, https://sociedip.files.wordpress.com/2013/ 12/protocolo-de-santa-marc3ada-sobrerelaciones-de-consumo.pdf (last accessed 14/1/2017).
} 


\footnotetext{
${ }^{52}$ See Protocolo de Olivos para la Solución de Controversias en el Mercosur, http://www.mercosur. int/innovaportal/file/722/1/cmc_2002_protocolo_de_olivos_es.pdf (last accessed 14/1/2017).

The most significant input in the protection of consumers arose from the enact- ment of Law 24.240, in the year 1993; its subsequent amendments, together with the enactment of the new Civil and Commercial Code, Law 26.994, in 2014,55 show a tremendous legislative concern towards Consumer Law.

Developments of law, case law and texts of authority have allowed for the consumer to be accepted as a "new vulnerable one" in the new Civil and Commercial Code. This characterization was deemed necessary to protect consumers in free markets, and users of public services. Public service providers act under a natural monopoly, and the application of Law 24.240 to them has been accepted by most of the Constitutional Law scholars. ${ }^{56}$

In general, there seems to have been a great advance in consumer protection in the recent years, but a difficulty lies in how to define the consumption relation appro- priately so that it can be applied to the cases specifically considered, without stretching it to cover simply any kind of contract. For instance, there has been an attempt to extend the concept of consumption relation to airline passengers but most of the authors consider that the airline passenger is not a consumer but a party to an air transportation contract, instead.

Our personal opinion is that, since 1993, the year in which Law 24.240 was passed, there has been a great advance in the matter of consumer protection.

Undoubtedly, consumers, in Argentina, enjoy protection. Were we asked to numerically rate the consumer protection system, both from an administrative and a judicial viewpoint, we would risk giving grade of 6 over $10^{57}$ to consumer satisfaction in Argentina.

\footnotetext{
${ }^{55}$ Law 26.994, http://www.infoleg.gob.ar/infolegInternet/verNorma.dø2id 235975 (last accessed 14/1/2017).
} 
${ }^{56}$ Against this position: Sacristán (2011), pp. 925-937.

${ }^{57}$ This grading is, in a way, related to the number of complaints published by the government of the

Ciudad Autónoma de Buenos Aires, Dirección General de Estadística y Censo - Ministerio de Hacienda GCBA (2015), Anuario Estadístico - Ciudad de Buenos Aires, http://www. estadisticaciudad.gob.ar/eyc/wp-content/uploads/2016/10/anuario_estadistico_2015.pdf (last accessed 14/1/2017), pp. 343-345, and its total population (around 2.8 million inhabitants).

\section{References}

Risolía MA (1946) Soberanía y crisis del contrato en nuestra legislación civil. Valerio Abeledo, Buenos Aires

Rojo M (2012) La defensa del consumidor en el Mercosur. Aequitas 6(6):1-18

Sacristán EB (2004) El principio 'in dubio pro consumidor' y los servicios públicos. In VVAA, Servicios públicos. Regulación. Primer Congreso Nacional, Diké Foro de Cuyo, Mendoza, pp 449-463.

Sacristán EB (2011) Tutela de los usuarios de los servicios públicos: ¿Es la relación de consumo compatible con el servicio público?, Derecho Administrativo. Revista de Doctrina, Legislación, Jurisprudencia y Práctica, Buenos Aires, Abeledo Perrot, Oct.-Dec. 2011, $\mathrm{N}^{\circ} 78$, pp 925-937

Sacristán EB (2016) Amparo colectivo en la Argentina: opt-in, opt-out o tal vez nada, Revista Argentina de Derecho de la Energía, Hidrocarburos y Minería, Buenos Aires, Ábaco, $\mathrm{N}^{\circ} 11$, pp 199-213

Shaver MA, An S (eds) (2014) The global advertising regulation handbook. Routledge, London, $\mathrm{p} 43$

Stiglitz RS, Pizarro RD (2009) Reformas a la ley de defensa del consumidor. La Ley, Buenos Aires, pp 949-960 